\title{
Myth Deconstruction of Wayang Ramayana and Baratayuda in the Novel of Kitab Omong Kosong by Seno Gumira Ajidarma and Perang by Putu Wijaya
}

\author{
Tjahjono Widijanto ${ }^{1}$, Herman J. Waluyo ${ }^{2}$, Suyitno33, Suminto A. Sayuti ${ }^{4}$ \\ 'Student of Doctorate Program of Universitas Sebelas Maret \\ Postgraduate of Universitas Sebelas Maret Surakarta, Indonesia \\ 2,3Faculty of Teacher Training and Education, Sebelas Maret University, Surakarta, Indonesia \\ ${ }_{4}^{4}$ Faculty of Language and Art, Yogyakarta State University, Yogyakarta, Indonesia \\ Corresponding email: tjahwid@yahoo.co.id
}

\begin{abstract}
The purpose of this research is to examine the deconstruction of the myths of wayang in the novels of Kitab Omong Kosong and Perang. Those myths including satriya myths, the myth of warfare and desacralization of puppets. Discussion conducted using a typical perspective of deconstruction; first, deconstruction offers a way to identify contradictions in text politics or ideological tendencies that appear in good text consciously or unconsciously. Second, literary texts and traditions are treated which are able to open up new possibilities to conceive and open a new possibility of change that was considered impossible. Third, through a deconstruction point of view, ideology that has frozen in language and mind can be liquidated. The results of the discussion show the novel KitabOmongKosong, and Perang, a critical view of the satriya myth (RamaLaksmana and Pandawa). Rama, Laksamana and Pandawa voiced in the novel is no longer fit with the myth of perfect satriya in wayang play (satriyapinandita) who representing truth, just and powerful, but reckless. Yet they are depicted as evil, and ridiculous. The war that was carried out by Rama and the Baratayuda (Pandawa versus Kurawa) which is written in puppet as a holy war between evil and goodness is only the war that arises because of power ambitions. The research results shows that the myths in wayang have been dismantled and reconstructed by Seno Gumira and PutuWijaya to express and the authors express their views and appreciation of the problems of present socio-cultural life.
\end{abstract}

Keywords: deconstruction; myths; satriya; wayang /puppets

\section{Introduction and Literature Review}

By its existence, a novel can express, bring and question certain myths. According to Umar Yunus, literary works, especially novels, both old and new, essentially carry myths. So, literary works can act as a myth of concern and can also present as a myth of freedom. A novel carries a myth of confirmation because the text of the literature strengthens or confirms existing myths. And it is referred to as the myth of inauguration if the literature text seeks to make changes, modifications, rebellions, or even dismantling or deconstructing a particular myth (Yunus, 1981: 63).

Literary texts also have correlation and relevance to other texts. This is because literatureas a mosaic of texts- is not created from cultural emptiness (Teeuw, 1980: 12). In this context, it can be said that a literary text is an "attitude" or response to other texts. "Attitude" or response can be

(C) AesthetixMS 2020. This Open Access article is published under a Creative Commons Attribution Non-Commercial 4.0 International License (http://creativecommons.org/licenses/by-nc/4.0/), which permits non-commercial re-use, distribution, and reproduction in any medium, provided the original work is properly cited. For citation use the DOI. For commercial re-use, please contact editor@rupkatha.com. 
interpreted as a compromise, response, answer or criticism that leads to the meaning of understanding. This is very possible because literature is essentially a continuous tension between the conventions- constructions of previous texts and innovation (Teeuw, 1980: 12).

Wayang or shadow puppet is one of the old myths that have played an important role in Javanese society while also become a source of inspiration and exploration for modern Indonesian authors. In Javanese society, shadow puppet shows (wayangkulitpurwa) are very popular. The audience in this performance sits on both sides of the screen; they can choose to watch wayang/ puppets behind the screen or in front of the screen. The shadow puppet show in Java has become a myth as an effort to ensure that everything is done well and to prevent all hazards, or to reject balak (Suseno, 1993: 160; Haazeu, 1979: 21)

Puppets or wayang are considered as a myth that gives certain guidelines and directions to society (a group of people), can give direction to human behaviour and human wisdom guidelines. Through this myth, humans can take part in surrounding events and can respond to the forces of nature (Peursen, 1989: 37). Wayang/ puppet is a mirror of the life of Javanese people and society. In wayang, Javanese people look for their own figures, images that they project at any time and have long been interpreted in a standard meaning and placed in the sacred, mystical stage and full of Javanese theosophical teachings (Mulder, 1986; Amir 1988; Moertono, 2017).

Wayang stories in Javanese society are used as a means of expression for Javanese peoole's thoughts, knowledge and experiences in addressing their lives. Wayang/ puppets are the axis of Javanese unconsciousness and are considered as guidance of Javanese metaphysics and aesthetics. Javanese people in their daily life always try to find moral and ethical legitimacy of their behaviour, attitudes, opinions, views and perceptions in wayang. Self-identification is always done by referring themselves to wayang/ puppet characters. Good human beings are always identified and known through the characters of the characters Satriya Pandawa in Mahabharata or Rama-Laksmana in the Ramayana play, while humans with negative characters will be identified with figures of Kurawa or giants.

Culture or cultur is a very old concept. In the beginning culture was seen as a system of meaning synchronously and a historical. Then culture is seen as a unified whole with consistency and integration between its elements, and then culture is understood as a kind of social consensus about trust, basic attitudes, and proper disposition. But as a result of a paradigm shift, people are now more strategically looking at culture as a process of exchange and a complex process of influences in history.

Culture is a temporary and imaginative description of crosses of various streams (Sugiharto in Kristanto, 2004: 123) thus culture is forever characterized by inconsistencies, incoherence, deconstruction, reconstruction, whose meanings for our cognition are still in the process (Anderson, 1990: 45). Culture is a dynamic dialectical process, culture is not something given which naturally exists and will not change. Culture will always change and shift, but diluting the establishment of cultural figures will depend on the dialectical ingredients of various systems and values.

Culture when interpreted as a 'dialectical process that will continue to dilute the establishment' opens up the possibility to review, criticize and even reconstruct cultural meanings. The past culture is very open to be interpreted with new meanings which may be very different even contrary to the previous meanings, including Javanese culture. Javanese culture, which is a fairly old culture in the archipelago, had previously had quite strong meanings. But along with the changing times, Javanese people as supporters of Javanese culture itself, at a different time with 
different social situations, were forced to reinterpret according to the social context they experienced.

Wayang or shadow puppets is one of the examples, in the old cultural context, wayang/ puppets on Java are not only seen as spectacle but also guidance. Wayang/ puppets have even been interpreted in a meaning framework that is gripped and often placed in a sacred, mystical, and full of Javanese theosophical teachings (Mulder, 1986; Mulyono, 1978; Amir, 1988). But in the present context, wayang has the possibility of getting a new interpretation.

Wayang/ puppets can be considered as guidance to Javanese ethics and metaphysics. Through the wayang/ puppet, Javanese man cultivates his thoughts about himself, the world and the existence of the universe. The stories of wayang/ puppet plays are always based on basic scenarios about these things. What is called wayang is a shadow theatre played by a puppeteers/ dalang accompanied by gamelan which is a typical Javanese orchestra. Wayang/ puppet is a symbol of human experience and effort and its journey in an effort to obtain perfection of life. Wayang/ puppets function as mirrors of humans in the world while describing the processes of human life in a certain period of time.

Serat Centini vol. IX pupuh 598 states that wayang/ puppets and all their equipment such as colour, gedebok, blencong, cempala, etc. contain certain symbols related to human life and the universe. Wayang/ puppet shows are always displayed at important Javanese events to express the desire to mark a moment of safety and serenity (slamet) in life (Permanadeli, 2015: 90). Wayang/ puppet shows usually takes stories which are developed based on the stories of Ramayana and Mahabharata.

In real life, Javanese humans always seek moral and ethical legitimacy in behaviour, attitudes, perceptions or self-identification through wayang/ puppets. In everyday life, for example, self-recognition is always associated with referring to wayang/ puppet figures (Suseno, 1997: 158). Good people are always acknowledged through the characters of the satriya figures, especially the Pandawa figures or the characters of Rama and Laksmana in Ramayana. While the negative character or antagonist is identified with the Kurawa or giant figure. For Javanese people, wayang/ puppets are a reflection of life itself. That is why Javanese used to say that life is a play or lakon. Wayang is both the content and form of Javanese thought and value, which became a moral, ethical and even psychological reference of Javanese society.

Life mythology of the Javanese which is embodied in wayang/ puppet plays is rooted and ingrained and has even become a distinctive identity of Javanese society. Wayang/ puppet plays in Java are basically stories of the epics of the Ramayana and Mahabharata. Ramayana and Mahabharata are the biggest classics. Ramayana is older (in India) but comes later or younger in Indonesia (Amir, 1991: 39).

Ramayana was the work of walmiki (Valmiki) while Mahabharata was authored by Wiyasa (Vyasa). The epic of Ramayana entered and influenced Asia in the first centuries AD and entered Java and Sumatra through Gujarat from South India during the reign of Sriwijaya. The Ramayana consists of 24,000 seloka and is divided into seven kanda (volumes), namely (1) Bala Kanda; narrates the reign of King Dasaratain Ayodya and tells Rama (Sri Rama) to marry princess Sinta from the kingdom of Mantili; (2) Ayodya kanda, tells how Rama and Sinta's adventures with Laksmana (Rama's brother) in the forest for 14 years; (3) aranya kanda, telling how giant king Rahwana from Alengkapura kidnapped Sinta; (4) Kiskend kanda, recounting the alliance of Rama-Laksamana with monkey king named Sugriwa who then crossed the sea to attack Alengka with the mission to recapture Sinta; (5) sundara kanda tells how Anoman, a white ape, served as ambassador to meet 
Sinta; (6) Yuda kanda narrates the great Perang between Rama and Rahwana and Sinta return to Rama; and (7) Uttara kanda narrates the history of the children of Rama and sinta and the stories that are not in Valmiki's writings, are just an addition of a younger age (Muyono, in Amir 1991: 41).

While Mahabharata was originally manifested as oral literature which began with three generations of speakers or singers, namely the generation of Ugrasravas, Krishna Dvipayana (Vyasa) to the generation of Vaisampayana. Mahabharata consists of 100,0oo couplets so it is actually difficult to determine who actually wrote or fabricated the word, although it is generally acknowledged that Vyasa (Wiyasa) wrote it, and it is also difficult to know exactly when this great work was written (Butteman in Amir, 1991: 42). These 100,000 couplets in the Javanese version of Mahabharata are divided into 18 parwa. namely: adi parwa, saba parwa, wana parwa, parwa wirata, udyoga parwa, Bisma parwa, Drona parwa, Karna parwa, Salya parwa, Sautika parwa, Stri Parwa, santi parwa, Anusana parwa, Aswamedika parwa, Mausala parwa, Mahaprastanika parwa and Swargarohana parwa (Widijanto, 2011:)

The focus of this study will be the construction of wayang/ puppet myths found in the novel Kitab Omong Kosong by Seno Gumira Ajidarma inspired by the wayang/ puppet play Ramayana, and the novel Perang by Putu Wijaya which took the idea of the Baratayuda Perang from the Mahabharata. The myths studied include: (1) myths about satriya Rama-Laksmana and the myths of pandawa-kurawa, (2) myths of the Perang of Rama-Rahwana and the Perang of Barata Yuda; and (3) desacralization of wayang or wayang/ puppets.

According to Derrida, deconstruction is not a theory or a system of thought but rather a tactical effort designed to prove language instability and faltering foundations which form the basis of most existing theories (Sim, 2002: 59). In the concept of Derridian discourse, meaning is always in the process so that it does not have a standard and permanent meaning. Related to this, Jonathan Culler (in Rahman, 2014: 19) explains that deconstruction is a form of complete freedom in interpretation. Nurgiyantoro (2009) considers that deconstruction is essentially a way of reading text that subverts the notion that the text has a foundation, has a system of language to emphasize structure, integrity and definite and certain meanings. More explicitly it is said that deconstruction is a rejection of logo centrism. Deconstruction focuses on continuous effort to destroy and eliminate centralization (decentring) (Faruk, 2013: 120).

Kristeva (1980: 36-37), explained that deconstruction is a combination of destructive and constructive nature. Deconstruction is a way of reading text, as a strategy. Deconstruction is not merely shown in writing, but all cultural statements because the whole statement is a text which in itself already contains certain values, prerequisites, ideologies, truths, and goals. Deconstruction is thus not only limited to engaging in discourse studies, both oral and written, but also other forces that effectively transform the nature of discourse.

Deconstruction is said to be a method of reading text. With deconstruction, it is shown that in every text there is always an assumption that is considered absolute. In fact, every assumption is always contextual: the assumption is always present as a historical social construction. That is, these assumptions do not refer to the final meaning. These assumptions are present as traces that can be traced to their formation in history.

Umar Junus (1996: 109-109) views deconstruction as a new perspective in literary research. Deconstruction actually provides an impetus to find everything that has not received attention. It is possible to do intellectual exploration with anything, without being bound by rules that are considered to be universally valid. Deconstruction, broadly speaking, is a way to bring the contradictions that hide behind our concepts so far and the inherent belief in this self before us. 
In short, it can be concluded that the main aspirations of deconstruction are to uncover the meanings that have been marginalized, ignored or neglected, and which have been hidden. When interpretation must follow the standard rules that are guarded and supervised by authority, deconstruction is present to disturb and sue the authorities. Examine what has been validated and guarded by tradition and history.

People are commonly used to understanding Derrida's deconstruction as a form of stance that is aggressive, radical, shakes, moves, destroys, dismantles and questions, giving rise to sceptical thinking. Even though deconstruction is actually a combination of destructive and constructive nature (Kristeva in Ratna, 2005: 203). For this reason, it is suitable for us to reflect on Goldschmidt's opinion which offers another perspective: Without being able to laugh at ourselves, deconstruction will not be possible (in Haryatmoko, 2016: 133).

\section{Method}

This study uses textual qualitative and interpretative approaches with a focus on the novel's extrinsic problems, the myths and deconstruction of myths found in novels (Wellek and Wargeen, 1990; Darma: 2004; Mahayana, 2010; Yunus, 1984). The novel studied is Kitab Omong Kosong by Seno Gumira Ajidarma and Perang by Putu Wijaya. Data analysis techniques used are descriptiveinterpretive techniques based on hermeneutic theory. Literary texts need to be interpreted because literary texts are built using language tools that have many hidden meanings or intentionally hidden (Ratna, 2010: 44-45). Hermeneutic tries to understand the literary meaning behind the structure. Understanding of meaning is not only a symbol but also views literature as a cultural text, for which researchers must swoop toward deepening the text and context so that the whole meaning is found.

Simple data analysis techniques which include three phases: (1) sequencing and understanding of meanings in the novel as a whole and transient, (2) expansion and explanation of meanings by linking the content of novel texts and cultural contexts by deconstruction reading, and (3) utilizing facts the facts found in the novel as a reference point criticize the myth of the wayang myth. Validity of data is done by reading and reviewing repeatedly in a circular process to gain an understanding of meaning that is adequate and sharpened through peer discussions.

\section{Result and Discussion}

\section{Deconstruction of the Myth of Satriya}

The Javanese wayang myth is the culture of satriya or ksatriya, the ideal concept of Javanese man reflected in wayang is satriya pinandita, the ideal life of a knight or leader who has the character of satriya as well as a sage. In the myth of satriya as this ideal human being, the ksatriya in wayang are always displayed as brave, defender of truth and have impeccable morality. Because he is perfect in his acts, deeds and thoughts, the figure of the satriya must be imitated by the common people or the kawula alit. This noble Satriya in wayang that takes stories from the Ramayana are characterized into the characters of Rama, Laksamana, and Wibisana. While for the wayang/ puppet plays that take stories from Mahabharata, these Satriya figures are the Pandavas (Yudistira, Bima, Arjuna, Nakula and Sadewa, and their children)

In wayang, the concept of Javanese leadership is always identified with the king with the value of the Satriya. The king of the Satriya is titled as God's personification (God's revelations), 
therefore he is absolute. The myth of this king of Satriya in the story is said by the dalang as "ratu satriya gung binathara bau denda anyakrawati, wenang wisesa ing sanagari, ber budi bawa leksana, ambeg adil paramarta " (the king of the empire who has the power of the gods, the keeper of the law and the ruler of the world, the highest power of the whole nation, full of noble character and fairness toward one another).

In the novel Kitab Omong Kosong (KOK), from the beginning immediately appears a mythic rebellion or deconstruction of the character Rama as satriya. Rama's figure in the Ramayana was posted as a figure of Satriya who always carried the righteousness, enforced justice and avoided all bad behaviour, while in the novel he is precisely described as a cruel, fascist and power-hungry king. This is shown in the following quote:

"In a short time the name Sri Rama, who was previously become so popular, so fragrant, as the conqueror of the land of Alengka, turned out to be a very frightening name. From Magada, the army of Ayodya continued to sweep Angga, Campa, Mantura and Banggaeven way to the shore. The beautiful city of Malini turned into a sea of fire. People are pushed to the shore. That is where the cruel slaughter happened. People who have given up raising their hands with half of their bodies in the sea were mercilessly killed until the beach is full of dead bodies "(Ajidarma, 2013: 16).

The quote from the novel above shows an attempt to unravel the myth of Rama in the wayang/ puppet. During this time in the wayang/ puppet play, Rama's figure is titled as an avatar of God Vishnu who is a god who serves as the protector and saviour of the world. As the personification of Wisnu, the figure of Rama in the wayang is mythed as a man who always serves as a human being who always memayu-mayu hayuning bawana (always maintaining the peace of the world), but the mysterious KOK novel is dismantled and inverted by raising a cruel Rama figure, bloodthirsty and power-hungry.

While in Putu Wijaya's Perang (P) novel, it is also found demolition or deconstruction of myths related to the Mahabharata. In the wayang story that comes from the Mahabharata, figures of satriya Pandawa, such as the character of Rama in Ramayana, are also imaged or posted as satriya who always carry out righteousness, always praised, enforcers of justice (satriya pinandita satriya awatak pandita) and holders of just / wise power / government (queen of gung binathara, ambeg adil paramarta), whose existence is always contrasted with the existence of a giant Kurawa which is symbolized as a symbol of evil and malevolent. But in the novel Perang, the figures of the Satriya Pandawa both Yudistira, Bima, Arjuna, Nakula and Sadewa are described as having the same characteristics of evil and bad as Kurawa

The Pandavas as satriya are no longer positioned as a symbol of goodness that must deal with the enemy of truth, but instead are described as so troublesome and busy facing their own problems, and full of personal ambitions. As seen in the data in the form of the following quote:

Bagong with his hand on his waist said. "This is the problem. People who dare to say the truth is said to be insulting ... Just imagine, Abhimanyu is still young, even he can't wipe his own arse, so what's the reason the palace has been made for him. Soon after the fence of the house just got a bit bump, the house immediately repaired, solely because Arjuna wants to have a new palace to accommodate the harem slaying around. What kind of madness is this? Whyhis personal interest is became troublesome for everyone ... (Wijaya, 2001: 93).

In the quotation above data, there is a situation that is not possible in the Javanese wayang/ puppet play, where the Pandavas ask themselves the existence of "kesatriyaannya". The quote above illustrates that the Pandawa in the myth of wayang is sartiya binatara, ideal man, commendable, 
full of wisdom, a leader who serves, in the novel Perang is actually deconstructed as a source of complexity and problems with his personal ambitions. Even Pandawa "naughtily" deconstructed in this novel in how the figures of the Pandavas are bored of being kept as satriya who always take sides and refer to the truth. Even in other parts (pp. 280 and 281), for example, physical deconstruction of the form of the Pandavas is physically demonstrated. Bima suddenly wanted to look slim and he was actively exercising in gymnastics, Nakula Sadewa was busy in entrepreneurship, Arjuna has hobbies in lecturing and giving religious sermons, opposing polygamy and promoting family planning, and Yudistira, with his hobby of traveling and culinary.

From some of the quotations above, it can be seen how in the KOK and P novels, the author deconstructs satriya myths in Ramayana and Mahabharata. The concept of satriya as Javanese ideal human beings embodied in the characters of Rama and Pandawa figures is deconstructed and turned upside down. The concept of Satriya Rama and Pandawa, which has been an ideal myth as a just person, serving the community, a symbol of truth and so on, has been reconstructed as the opposite of the ideal human concept.

In simple, deconstruction or dismantling of myths in both novels can be summarized in the following chart:

Table 1: Myths Deconstruction

\begin{tabular}{|c|c|c|c|c|}
\hline $\begin{array}{l}\text { Name of } \\
\text { Satriya }\end{array}$ & Source & Novel & Myth & Myth Deconstruction \\
\hline Rama & Ramayana & $\begin{array}{l}\text { Kitab } \\
\text { Omong } \\
\text { Kosong }\end{array}$ & $\begin{array}{ll}\text { 1. } & \text { Wisnu's incarnation } \\
\text { 2. Passionate } \\
\text { 3. Defender of the truth } \\
\text { 4. Patient } \\
\text { 5. Trustful } \\
\text { 6. Guardian of world peace } \\
\text { (memayumayuhayuningbawana) }\end{array}$ & $\begin{array}{l}\text { 1. Fascist } \\
\text { 2. ambition for power } \\
\text { 3. Cruel } \\
\text { 4. Uncompromising } \\
5 \text { full of Rage } \\
6 \text { Destroyer of Peace }\end{array}$ \\
\hline Laksamana & Ramayana & $\begin{array}{l}\text { Kitab } \\
\text { Omong } \\
\text { Kosong }\end{array}$ & $\begin{array}{l}\text { 1. Wisnu / Rama's companion } \\
\text { 2. Compassion } \\
\text { 3. loyal } \\
\text { 4. Just } \\
\text { 5. Defender of Righteousness } \\
\text { 6. Guardian of Peace }\end{array}$ & $\begin{array}{l}\text { 1. } \text { Cruel } \\
\text { 2. Fierce } \\
\text { 3. Bloodlust } \\
\text { 4. Furious } \\
\text { 5. Destroyer }\end{array}$ \\
\hline
\end{tabular}




\begin{tabular}{|c|c|c|c|c|}
\hline Arjuna & Mahabharata & Perang & $\begin{array}{l}\text { 1. Lelananingjagat(Playboy) } \\
\text { 2. Humble } \\
\text { 3. Ascetic (Sage Life) } \\
\text { 4. Polygamous } \\
\text { 5. compassionate }\end{array}$ & $\begin{array}{l}\text { 1. Lazy } \\
\text { 2. Greedy } \\
\text { 3. Drunkard and wasteful } \\
\text { 4. Monogamousand hard } \\
\text { supporter of Family } \\
\text { PlanningProgram } \\
\text { 5. Stingy }\end{array}$ \\
\hline Bima & Mahabharata & Perang & $\begin{array}{l}\text { 1. Firm } \\
\text { 2. Honest } \\
\text { 3. Discipline } \\
\text { 4. Humble }\end{array}$ & $\begin{array}{l}\text { 1. Full of Compromise } \\
\text { 2. Talk too much } \\
\text { 3. Lazy } \\
\text { 4. Greedy and Drunkard }\end{array}$ \\
\hline Yudistira & Mahabharata & Perang & $\begin{array}{l}\text { 1. Wise } \\
\text { 2. Patient } \\
\text { 3. Honest } \\
\text { 4. Ascetic/ Monk-like life } \\
\text { (distancing from worldly } \\
\text { matter) } \\
\text { 1. Loyal }\end{array}$ & $\begin{array}{l}\text { 1. Clumsy } \\
\text { 2. Liar } \\
\text { 3. Sly } \\
\text { 4. Love sightseeing and } \\
\text { culinary }\end{array}$ \\
\hline $\begin{array}{l}\text { Nakula } \\
\text { andSadewa }\end{array}$ & Mahabharata & Perang & $\begin{array}{l}\text { 2. Humble } \\
\text { 3. Good Warrior }\end{array}$ & $\begin{array}{l}\text { 1. Not Reliable } \\
\text { 2. Greedy } \\
\text { 4. Businessmen and } \\
\text { entrepreneurs }\end{array}$ \\
\hline
\end{tabular}

\section{Deconstruction of the BarataYuda and Ramayana War Myths}

In the Javanese wayang/ puppet myth originating from the Mahabharata, the war between the Kauravas and Pandavas, known as the Baratayuda or the war between Rama and Rahwana / Dasamuka, known as Brubuh Alengka, both have a clear concept of who is the opponent who is friend. In the barata yuda, the opposite is very clear, the Pandavas as the satriya party symbolizing the good against Kurawa as a symbol of evil. Likewise in the Perang between Rama and Rahwana, Rama becomes a symbol of truth and Ravana symbol of evil. But in both novels between opponents and friends is not clear.

"Who is our opponent actually?" Petruk asked at midnight at Gareng. Gareng Shocked. He looked at Petruk with strange eyes (Wijaya, 2001: 16)

Bagong approached his father. His face looked earnest, Semar was made wonder.

"Why are you Gong, sick?"

"No sir. I want to ask sir"

"About what?"

"Who are our enemies?" (Wijaya, 2001: 17)

"I have been tempted by the question from Bagong. Who exactly is our enemy?

All this time we all know, our enemy is Kurawa. But is the answeras simple as that. Are there no other more powerful enemies. The problem is thatit is clear later in the Baratayuda war that the Kurawa will definitely lose ... "(Wijaya, 2001: 123)

The questions of the characters in the quotation clearly cannot be found in the wayang/ puppet play. In these quotations the concept of Baratayuda war becomes something that is blurred and no longer firm. Between those who are hostile, the right and the wrong melt, they even melt 
away the binary position between good and bad ... Even in the next quote below, the wicked party which has been represented in Kurawa has also melted away. The wrong party can change into the position of the Pandawasatriya.

"Wrong? What kind of wrong Truk?"

"It's so wrong! Because you think Kurawa is rotten!"

"Is it NOT rotten?"

"Your thoughts are rotten! Everything you see becomes rotten!" (Wijaya, 2001: 53)

From the data quoted above, there appears to be a deconstruction of the myth that the Kauravas were not always the bad or rotten party, but the Pandawa could be more rotten than the Kuravas. The myth that has so far occupied the position of satriya Pandawa as a symbol of goodness has begun to be questioned and reconstructed.

Even in the quotation below it is clearly shown that in Baratayuda war, the one who took the initiative was the Pandavas knowing that they will win in Baratayuda war. Baratayuda begins with intentions of Pandawa who annexes Kurawa:

Bagong was fascinated.

"You mean they don't want to annex us?"

"... No, we are fishing them. Because it is prophesied that in Baratayuda warthey will be broken and we will win "(Wijaya, 2001: 60)

From the quotation above it seems clear that the author boldly deconstructed the myth of Baratayuda war. Baratayuda is no longer a symbol of evil versus good but transformed into war solely because of power and politics and it was precisely. The Pandawa who became the initiator of the war. The Kurawa, which has been a symbol of the keangkaramurkaan or lelethekingjagad (symbol of evil) that must be eliminated, is not as bad as what are in our minds. Pandavas can one day change to have the nature of Kurawa and vice versa Kurawa can be as good as the Pandavas. In this case the binary opposition was destroyed.

While in the novel Kitab Omong Kosong, Rama who is in the Ramayana story is titled as the god of Vishnu who is in charge of saving the world, and when Rama do warfare, it is a holy act that must be done because it is an obligation to destroy evil. In Javanese it is said to sura dira jayaningrat lebur dening pangastuti (no matter how great the power of evil is, the evil will eventually be destroyed by truth and kindness).

But in the KOK novel, Rama is actually the initiator for conducting a series of war and looting just because his lust to rule the world. Even the war waged by Rama and Laksmana had destroyed world civilization. As shown in the following quotations:

"This is the result of Sri Rama's Horse Offering war. After millions of people died, tens of millions of lives are now displaced. We live in world which has been destroyed by War. These refugees are scattered in various directions, now all want to go back, but their country is left in ruins scattered about ..."

... (Ajidarma, 2013: 93)

... The Disaster of the Horse Offering, even though it only lasted a year, had devastated the life of the entire continent for an indefinite time, like a deep wound, creating millions of homeless and stateless homeless people who lived only on prayer ... (Ajidarma, 2013; 121)..

"....... Sri Rama called me to help him, but I refused and returned to the eternal dimension where immovable space and time could be reversed. There I saw the terrible destruction 
which had been caused by various looting, burning, and massive destruction. Human culture returns to zero. Scholars are exterminated, colleges are levelled and too many people live with their wild instincts. "(Ajidarma, 2013: 281)

From the descriptions above, it appears that both the Perang novel and the Kitab Omong Kosong attempt to demolish or reconstruct the myth of war in wayang/ puppet plays. In wayang stories both from the Mahabharata and Ramayana, war is always written as a holy battle between truth against falsehood, between good and evil. But it is precisely in the two novels that the Barata Yuda War and the war carried out by Sri Rama (Ramayana play) are only the result of an ambitious ruler. The ironic thing is that the ruler is a group of satriya pandawa or Rama-Laksmana whose stories are always written as symbols of truth.

\section{Desacralization of Wayang/ Puppets}

In Javanese traditional society, stories and wayangpurwa show (hereinafter read: wayang/ puppets) are very popular. In wayang, human life in this world is described as a shadow. Wayang/ puppets in Javanese society are considered as ethical guides and metaphysics in which thought is thought about human existence, the world, and the existence of the universe. (Suseno, 1997; Amir, 1986; and Mulyono, 1995). Even in the serat Centini volume IX pupuh 598 it is stated that wayang/ puppets and their equipment such as kelir, gedebog, blencong, cempala, etc. are symbols that are related to transcendence.

In wayang, it is depicted how event after event and purpose of life take place in certain stages. Human life takes place in a given pattern, and therefore is inevitable. The given pattern of life applies to everyone. That is, the fate of the person per person is already written and certain: humans can only get pestha, but the pesthi is absolutely the property of "Sing GaweUrip" or the creator of life. This is commonly referred to as the principle of pepesthen. Everything was confirmed beforehand. All things must follow the direction that has been determined and in line with the rules of the cosmos. Sing GaweUrip is a transcendental substance, which includes everything, and which is the origin and last destination: sangkanparaningdumadi (Sayuti, 2013).

The theme in wayang/ puppet is the theme of certainty and is far from the theme of possibility. The world of wayang/ puppets is a world of certainty. The dynamics and dialectics of wayang/ puppets, especially when played by puppeteer in a performance, are a symbol of human life in this world. He gives instructions on how we must live in fulfilling our purpose in the world. Therefore, reading and watching wayang/ puppets will also mean as a process of identifying with certain characters and reflecting and modelling on them in doing actions in daily life.

Wayang/ puppets in Javanese society are also regarded as something sacred and mystical. Even in several carangan plays, wayang/ puppet shows are held as a means to achieve something, release certain nadar or efforts to avoid the disaster (Ruwatan). There are also certain plays that are made for the purpose of giving enlightenment and understanding of mysticism, for example, DewaRuci or BimaSuci. DewaRuci's play is the essence of the teachings of Javanese theosophy which explains the relationship between humans and their Creator. Many names of characters in wayang are considered as the embodiment of pure and sacred gods. For example, Rama is considered the incarnation of Lord Vishnu and Sinta as the incarnation of DewiLaksmi. The figure of Arjuna as an embodiment of DewaIndra, Yudistira as the incarnation of Lord Brama, Semar as a master ruler of the land of Java.

But in both novels, both KOK and P, the author performs the deconstruction of something that is considered sacred. Satriya figures are no better than giant characters or magical creature. Even in KOK, it is described as how Walmiki the author of Ramayana considers what he wrote was 
nothing more than a game and even allowed the characters to choose the way of life and the ending of his own story. The characters break away from the stories that they make, take their own stories, form new stories and even the characters meet other characters Ajidarma, 2013: 317).

In the myths of Javanese wayang/ puppets, figures of punakawan/ clowns, especially Semar, have quite complex proportions. The clowns served as protectors and saviours of the ksatriya because it was considered sacred. This sacred myth emerged because the existence of the figure of the clowns were actually the incarnation of the Gods. Semar, for example, is the incarnation of god Ismaya who is in charge of escorting, assisting, protecting, rescuing, caring for and advising the satriya so that they are able to carry out their deeds as the chosen decree. In another dimension, the figure of the clown is considered as a symbol of the alit or common people, as the lowest structure in the state administrative ranks.

The existence of punakawan /clowns, especially the character Semar in wayang/ puppets, is written as something sacred that is deconstructed in the novel. In the novel Perang, the Semar character instead appears as a person who is not intimate but who is dissatisfied with his physical appearance which is not comparable to satriya so he feels embarrassed and desperate to do plastic surgery to beautify the shape of his mouth, as shown in the following quote:

Steadily then Semar again met the doctor, stating his purposeto cut the excess of his mouth, ready to repair his identity and ready to maintain harmony (Wijaya, 2001: 241)

In the quotation above, the Javanese wayang/ puppet the myth usually regard Semar as the incarnation of a wise god, who is always grateful for the blessings given and has never regretted the physical existence is depicted to have "protests" and determines the resistance to destiny. Even illustrated, the character of Semar became a figure who likes to drink wine until drunk as shown below:

Semar which is still influenced by wine laughs out loud. ... "This is due to wine, don't put it too deep down. All of this is nonsense, it's just me mumbling while drunk ", said Semar while giggling ... (Wijaya, 2001: 250)

Even more extreme deconstruction is seen by the author when describing how Semar behaves like a playboy like Arjuna who likes to hunt women and cheat:

Semar instead tried to replace Arjuna. Within three years he had succeeded married three women ... (Wijaya, 2001: 282)

From the quotation above, it is shown how the character of Semar was no longer trapped as a pemomong who was a good adviser to the satriya, but instead committed an inappropriate deed. TheOldSemar actually lusts for women.

In the KOK concept, the form of wayangdesacralization also appears with the emergence of the figure of punakawanTogog as the protagonist and plays an important role as the saviour of civilization. So far in wayang, the punakawan who is considered more important, sacred and considered good is Semar, while Togog is more positioned as something that is not important and just as a supplement to the story. But in KOK it is Togog that is raised as a central figure who saves the world, not Semar.

In wayang, punakawan /Clowns are always presented as simple, kind, honest and wise. But, in the hands of writers Seno GumiraAjidarma and PutuWijaya, through the two novels wayang is "being played", overhauled, even dismantled so that they were no longer present as "the sacred" but were present as something light, fluid and satire. Wayang/ puppets are no longer confined as something sacred but as something light, irony and profane. 


\section{Conclusion}

In Seno Gumira Ajidarma's Kitab Omong Kosong books inspired by the story of Ramayana and Putu Wijaya's Perang novel sourced from Barata Yuda (Mahabharata), there is an attempt to dismantle the myth of wayang. The dismantling of the wayang/ puppet myths includes (a) deconstruction of the satriya myth, (b) deconstruction of the myth of war in wayang; and (c) desacralization of wayang/ puppets.

The dismantling of the satriya myth in the KOK novel is shown by the figures of satriya Rama and Laksmana. In the myth of wayang, satriya is a symbol of the ideal human being who is in charge of maintaining the peace of the world. Rama is the satriya incarnation of Lord Vishnu who is the guardian deity of the universe and Laksmana is a loyal follower and companion of Rama. But in the KOK satriya myths Rama and Laksmana are deconstructed so they are no longer presented as the protector of the world of security but are as bearers of disaster for the world.

The deconstruction of the myth of satriya in the Perang novel is shown by the Pandawa figures (Yudistira, Bima, Arjuna, Nakua and Sadewa). When in wayang, the five Pandavas figures are regarded as the leading satriya of fair, honest, simple, and always upright, in the novel of the Perang painted is no better than the Kurawa who in the wayang/ puppet is always mythed as a bad party.

In the novel Kitab Omong Kosong there is the disassembling of myths about war in wayang. In the wayang myth, war carried out by Rama as the incarnation of Vishnu and his younger brother Laksamana is always a symbol of the war between good and evil which is always won by good. But in the novel Kitab Omong Kosong the war carried out by Rama and Laksamana was deconstructed as a war only because of the ambitious power and occupation that brought the destruction of the world.

In the novel Perang, found the dismantling of myths about the BarataYudawarin the story of Maha Barata. In wayang Barata Yuda was posted as a holy warwhere good will defeat evil. Baratayuda must occur because it is a sacred duty for the Pandavas as a symbol of truth against Kurawa as a symbol of evil. In the novel Perang of the Pandavas actually questions the benefits of BarataYuda even thinks that Kurawa is not the wrong and evil party.

In the novel Perang and Kitab Omong Kosong there is an attempt to de-sacralisewayang/ puppets. This desacralization is shown how the wayang/ puppets with all the characters are dismantled, reconstructed and overturned. Sacred wayang/ puppet figures, for example the character Rama as the incarnation of Vishnu, the Semar character as a human holy man, dismantled and deconstructed so as not to appear sacred again but to be very fluid, light and satire.

\section{References}

Abdullah, T. (1994) Sastra dan Akar Tradisi. Horison, XXVIII (OI): 4.

Ajidarma, S. G. (1994). 11 Desember. Fakta dan Fiksi. Kompas.Hal. 17.

Ajidarma, S. G. (1995). 12 Februari. Keindonesiaan. Kompas, hal. 17.

Ajidarma, S. G. (2004). Kitab Omong Kosong.Jakarta: Gramedia.

Amir, Hasyim. (1994). Nilai-nilai Etis dalam Wayang. Jakarta: Sinar harapan. 
Myth Deconstruction of Wayang Ramayana and Baratayuda in the Novel of Kitab Omong Kosong by Seno Gumira Ajidarma and Perang by Putu Wijaya

Anderson, B. R.O.G. (1982). Sembah-Sumpah, Politik Bahasa dan Kebudayaan Jawa. Prisma, XI (11): 69-96.

Anderson, B.R.O.G.(1990). Language and Power: Explorring Political Cultyral in Indonesia. Ithaca, New York: Cornell Universitry Pres.

Anderson, B.R.O’G.(1990). Kuasa Kata Jejak Budaya-budaya Politik di Indonesia. Yogyakarta: Mata Bangsa.

Barau, A.S, Stringer, L.C, \& Adamu, A.U (2016). Environmental ethics ang future oriented transformation to sustainability in Sub-Saharan Africa..Journal of Cleaner Production, 135, 1539-1547. https://doi.org/10.1016/j.jclepro.2016.03.053

Barker, C. (2013). Cultural Studies. Teori dan Praktik. Yogyakarta: Kreasi Wacana.

Bertens, K. (1996). Filsafat Barat Abad XX Perancis. Jakar

ta: Gramedia.

Berkes, F. (2013). Religious Traditions and Biodiversity. Encyclopedia of Biodiversity, , 380-388. https://doi.org/10.1016/B978-0-12-384719-5.00122-2

Cipto Prawira, A. Tanpa Tahun. Filsafat Jawa. Yogyakarta: Javanologi.

Darma, B. (1995). Harmonium. Yogyakarta: Pustaka Pelajar.

Derrida, J. (1982). Margin Philosophy. Brighton: Harvester Press.

Derrida, J. (2000). Hantu-hantu Marx.Yogyakarta: Bentang

Dwiyanto, Dj. (2010). Ensiklopedi Wayang. Yogyakarta: Media Abadi.

Faruk, 1994. Sosiologi sastra dan Strukturalisme Genetik. Yogyakarta: Pustaka Pelajar.

Fukuyama, Francis. (1992). The End of History and the Last Man London: Hamish hamilton.

Hardiman,B.F.(1994). "Ilmu-ilmu Sosial dalam Diskursus Modernisme dan Pascamodernisme". Ulumul Qur'an Jakarta.

Haryatmoko. (2016). Membongkar Rezim Kepastian. Jakarta: Kanisius.

Mulyono, Sri. Ir. (1979). Simbolisme dan Mistisisme dalam Wayang.Jakarta: Gunung Agung.

Mustikas ari, D; Aldrin\& Luluk N. (2012). Stories of Wayang Di Batas AnginBy Yanusa Nugroho: Indonesian Wayang in Modern Literature. International of Economics Development \& Research Vol. 51. $\mathrm{Pl} 7$

Nurgiyantoro, B \& Anwar E. (2017). Re-actualisation of Puppet Characters in Modern Indonesia Fiction of The ${ }_{21}$ Century. 3L: The Southeast Asian Journal of English Language Studies- Vol 23 (2): 141-153. Http: //doi. Org/10. 17576/3L-2017-2302-11

Padmooekotjo, P.S. (1992). Silsilah wayang Purwa Mawa Carita. Surabaya: Citrajaya Mukti.

Pattaro, C. (2016) Character educatioan: themes and researches. An academic literature review. Italian Journal of Sociology of Educations, 8(1), 6-30. https://doi.org/10.14658/pupj-ijse-2016-1-2

Permanadeli, R. (2015). Dadi Wong wadon. Representasi Soaial Jawa di Era Modern. Yogyakarta: Pustaka Ifada

Pramudya Ananta Toer Perburuan, Journal of English Studies and Ccomparative Literature, Vol 2, No. 1, pp: 19-34. Online: http: //journal.upd. edu.ph/index.php/jescl/atricle/download/2479/2345

Probohardjono, S. (1957).SeratPakemwayangPurwa.Semarang: Dahara Prize.

Rusdy, S. T. (2015) Semiotika dan Filsafaf Wayang. Jakarta: yayasan Kertagama.

Sastrowardoyo, S. (1989). Pengarang Modern Sebagai Manusia Perbatasan. Jakarta: Balai Pustaka.

Sim, St. (2002). Derrida dan Akhir Sejarah. Yogyakarta: Jendela.

Slamet, Y. (2006). Metode Penelitian Sosial. Surakarta: LPP UNS. 
Soetarsa, S. K. (1964). Pakem Ringgit Purwa Lampahan Lahiripun Rama-Brubuh Alengka. Surabaya: Tri Murti. Sugiyono. (2011). Metode Penelitian Kuantitatif, Kualitatif, dan R $\mathcal{E} D$. Bandung: Alfabeta.

Sujamto. (1990). Sabda Pandita Ratu. Surabaya: Rajawali.

Sumukti, T. (2006). Semar, Dunia Batin Orang Jawa. Yogyakarta: Galang Press

Sunardi. (1986). Ramayana. Semarang: Dahara Prize.

Suyanto, B. (2005). Metode Penelitian Sosial. Jakarta: Kencana.

Ungkang, Marcelus. (2013). Dekonstruksi Jaques Derrida Sebagai Strategi Pembacaan Teks sastra. Jurnal Pendidikan Humniora.Vol.1.No. 1: 30-37. 